\title{
Contribution of Targeted Subsidies Law to the Equity in Healthcare Financing in Iran: Exploring the Challenges of Policy Process
}

\author{
Hamed Zandian ${ }^{1}$, Alireza Olyaeemanesh ${ }^{1,2}$, Amirhossein Takian ${ }^{1,3,4}$, Mostafa Hosseini ${ }^{5}$
}

${ }^{1}$ Department of Health Management and Economics, School of Public Health, Tehran University of Medical Sciences, Tehran, Iran

${ }^{2}$ National Institute of Health Research, Group of Payment and Financial Resources of the Health System, Tehran University of Medical Sciences, Tehran, Iran

${ }^{3}$ Department of Global Health and Public Policy, School of Public Health, Tehran University of Medical Sciences, Tehran, Iran

${ }^{4}$ College of Health and Life Sciences, Brunel University London, Uxbridge, UK

${ }^{5}$ Department of Epidemiology and Biostatistics, School of Public Health, Tehran University of Medical Sciences, Tehran, Iran

\section{Type of article: Original}

\begin{abstract}
Introduction: The Targeted Subsidies Law (TSL) was implemented in 2010 with a platform of improving equity in the Iran's society. One of the objectives of the TSL was improving equity in Healthcare Financing (HCF), but a significant change has not occurred since then. The aim of this study was to analyze the challenges of the TSL to equity in the HCF in Iran.

Methods: In this interpretive qualitative study, 31 policy makers and health system experts were interviewed face to face from September 2014 to June 2015. A purposeful and snowball sampling method was used to select participants. Also, a document analysis was conducted on upstream documents. Assisted by MAXQDA 10, recorded interviews were transcribed verbatim and analyzed based on Framework Approach.

Results: Content analysis identified two themes and five sub-themes. Lack of justice in the healthcare system and lack of equity in the total socioeconomic structure of Iran were sub-themes identified as barriers to equity in HCF. Shortcomings in the formulation, implementation, and evaluation of the TSL were sub-themes identified as barriers in the policy process. The TSL did not achieve its intended objectives in the health sector because of the above- mentioned barriers,

Conclusion: The TSL, according to established goals, had no effect on the equity in HCF in Iran because of problems in the structure of the health system, socioeconomic status, and the policy process. To reach a more equitable HCF, it is advised that, when defining the related policies, various barriers be considered, such as those identified in our research.

Keywords: government subsidy, healthcare financing, health planning support, policy making, socioeconomic factors
\end{abstract}

\section{Introduction}

When equity and equality comes to as goals in an agenda, governments try to direct resources towards vulnerable groups with the most need. For this purpose, various governments use different policies in different areas, such as Income Distribution and Poverty Elimination Policies in the social sector (1) and Universal Health Coverage (UHC) and Health Insurance Reforms in the health sector $(2,3)$. One of the useful policies for eliminating poverty and improving social justice is subsidies. There are different definitions for subsidies. In the MacMillan Dictionary of modern economics, subsidies are defined as governmental payments that cause pay gaps between consumers' and

\section{Corresponding author:}

Alireza Olyaeemanesh, National Institute for Health Research, Tehran University of Medical Sciences, Italia Ave, Tehran, Iran. Tel: +98.2188991109, E-mail: Arolyaee@gmail.com

Received: September 16, 2015, Accepted: December 22, 2015, Published: February 2016

iThenticate screening: November 22, 2015, English editing: January 13, 2016, Quality control: February 04, 2016

(C) 2016 The Authors. This is an open access article under the terms of the Creative Commons Attribution-NonCommercialNoDerivs License, which permits use and distribution in any medium, provided the original work is properly cited, the use is non-commercial and no modifications or adaptations are made. 
producers' costs (4). A study by the Organization of Economic and Co-operation of Development (OECD) defined subsidies in general terms, considered targeted subsidies, as intervention of government in the market and supplydemand cycle to support vulnerable groups and to promote the public welfare and economic development (5). All of these definitions address subsidies to solve inequity at the national and local levels and between peoples. Governments attempt to target subsidies for various purposes, such as decreasing the gap between the poor and the rich, modifying income inequality, modifying income distribution, increasing economic stability, and improving the society's overall well-being (6). For many years, the Iranian economy has been under pressure because of energy subsidies (7). The effects of the energy subsidies have been to increase the government's budget deficit and to create inflation, which were the main causes of increasing income inequality and decreasing social welfare (8). Given the experience of other countries and the economic situation in Iran, including high inflation, unemployment, low economic growth, low productivity of factors of production, an inefficient banking system, a weak private sector, low purchasing power, class differences, corruption, and the lack of economic transparency, reforming Iran's subsidy structure seemed necessary (7, 9-11). In 2010, the tenth government of Iran, in its "Economic Reform Plan," started to eliminate energy subsidies and replaced them with cash payments to the people. This plan was conducted to balance seven main axes of Iran's socioeconomic structure, i.e., reform of subsidies, tax system, customs, banking system, distribution of goods and services, national currency valuation, and productivity. The plan aimed to resolve the fundamental economic problems, including the lack of sustainable economic growth, unemployment, inflation, waste of resources, and the lack of social justice in the country (12).

Based on the World Health Organization (WHO) report 2000, to reach three main goals, i.e., responsiveness, health, and fair financing, all health systems should act properly in their four main functions, i.e., stewardship, financing, delivery of services, and creating resources) (13). To achieve these goals, several indicators were defined. One of the indicators for identifying fair financing in the health system is the level of justice in Healthcare Financing (HCF), which is measured by Out-Of-Pocket (OOP) expenses and the Fair Financing Contribution Index (FFCI) (14-16). Iran does not have an appropriate position in either of the indicators for equitable HCF between similar countries (17-19). One of the main purposes of TSL was to promote equity in society and in the healthcare system. To improve social justice, the policy makers added article 7 to the TSL in which paragraph B mentions the development and provision of social insurance, healthcare, security, and improved health and drug coverage and treatment of particular diseases and incurable diseases. This paragraph of the TSR is especially about the healthcare system. The main argument of this article and paragraph B are about how to use resources from TSL to improve coverage, improve the healthcare system, and improve the services and drugs, which are known to be the most important aspects that affect the health equity indexes (12). TSL was initiated on December 19, 2010. However, based on the results of different studies, indicators of equity in HCF have not changed significantly $(17,20,21)$. The aim of this study was to identify and explore the main defects and challenges of TSL in order to achieve its goals in the healthcare system four years after the implementation of the law. Equity in healthcare financing means that financial risks are distributed based on households' ability to pay (22). The results of the study, which was conducted by the World Health Organization's Eastern Mediterranean office in Iran in 2005, showed that the Fair Financing Contribution Index (FFCI) had a downward trend and the Catastrophic Health Expenditures (CHE) index had an upward trend in Iran's healthcare financing. Recent studies have shown that the CHE trend has not changed. During the last decade, the share of Out-Of-Pocket (OOP) expenses for treatment increased from 3.8 to $9.6 \%$ of the total costs $(17,21,23,24)$. So, according to the Targeted Subsidies Law's (TSL's) policy process and the status of equity in the HSF of Iran, the purpose of this study was to determine the challenges and defects of equity in HCF in Iran from the perspective of those who have the main influence over policies.

\section{Material and Methods}

\subsection{Research design and setting}

This interpretative, qualitative study explored the challenges of the targeted subsidies law in achieving its goals in the healthcare system. To do so, we obtained the viewpoints of 31 stakeholders and experts in the economics and health policy areas at the national level concerning the challenges of the targeted subsidies law in the health system field. The data were collected from September 2014 to June 2015 (10 months).

\subsection{Sampling}

The purposeful and snowball sampling method was used to select the participants. They were selected based on their relevant information about the health system, the Economic Reform Plan, and the Targeted Subsidies Law. The positions of participants with respect to decision-making, formulation, and implementation of the reform now and in the past decade were considered as including criteria. The number of participants was not determined in advance. In 
the study process, key informant participants were selected to interview to reach saturation in findings. Considering that, the study's policy question was important and complex, the number of participants was more than in other studies. Participants were from the Parliament of the Islamic Republic of Iran (Majlis) and highly-informed representatives of governmental organizations. Table 1 shows the position and characteristics of the participants. Data collection continued until data saturation.

Table 1. Characteristic of research participant

\begin{tabular}{|c|c|c|}
\hline Organization & Position & $\mathrm{n}$ \\
\hline Parliament (Majlis) & $\begin{array}{l}\text { Seven members of parliament from related commissions and former } \\
\text { senior policy officials }\end{array}$ & 7 \\
\hline $\begin{array}{l}\text { Organization of Targeted } \\
\text { Subsidies (OTS) }\end{array}$ & $\begin{array}{l}\text { - Former Director of OTS } \\
\text { - An expert from cash and non-cash subsidy office } \\
\text { - An expert from Department of Finance and Banking } \\
\text { - An expert from social security and treatment office } \\
\text { - Vice president of facilities and sartorial support }\end{array}$ & 5 \\
\hline $\begin{array}{l}\text { Ministry of Cooperatives, Labor } \\
\text { and Social Welfare (MoCLS) }\end{array}$ & $\begin{array}{l}\text { - Director of Social Welfare Studies } \\
\text { - An expert from social welfare office of MoCLS } \\
\text { - Vice President of Director General of Social Welfare Studies }\end{array}$ & 3 \\
\hline $\begin{array}{l}\text { Islamic Parliament Research } \\
\text { Center (IPRC) }\end{array}$ & $\begin{array}{l}\text { - Deputy of Economic Studies } \\
\text { - Senior Researcher of Management and Budget Office } \\
\text { - An experts of economic studies office }\end{array}$ & 3 \\
\hline $\begin{array}{l}\text { Social Security Organization } \\
\text { (SSO) }\end{array}$ & $\begin{array}{l}\text { - Director General of Education and Research } \\
\text { - Head of the Department of Economy and Planning } \\
\text { - An expert from the Department of Economy and Planning }\end{array}$ & 3 \\
\hline $\begin{array}{l}\text { Central Bank of Islamic } \\
\text { Republic of Iran (CBIR) }\end{array}$ & $\begin{array}{l}\text { - Head of the Monetary and Financial Institute } \\
\text { - Deputy of Economy of the Central Bank }\end{array}$ & 2 \\
\hline $\begin{array}{l}\text { Ministry of Health and Medical } \\
\text { Education (MoHME) }\end{array}$ & $\begin{array}{l}\text { - Director of the Center on Budget and Performance Monitoring } \\
\text { - One of the senior deputies of the MoHME } \\
\text { - An expert from Center on Budget and Performance Monitoring }\end{array}$ & 3 \\
\hline University professors & $\begin{array}{l}\text { - two university professors that had official position related to targeted } \\
\text { subsidy reform in the last decade }\end{array}$ & 2 \\
\hline $\begin{array}{l}\text { Management and Planning } \\
\text { Organization of Iran(MPO) }\end{array}$ & $\begin{array}{l}\text { - A Senior Advisor to the President of the organization } \\
\text { - Secretary of the targeted section of the organization }\end{array}$ & 2 \\
\hline $\begin{array}{l}\text { Ministry of Economy and } \\
\text { Finance (MoEF) }\end{array}$ & $\begin{array}{l}\text { - Deputy Economic Affairs of MoEF } \\
\text { - Director of the ministerial departments }\end{array}$ & 2 \\
\hline
\end{tabular}

\subsection{Data collection and analysis}

Semi-structured, face-to-face, in-depth interviews were conducted. The interview guide was designed by the main team of the study and based on the objectives of the study, and it was tested on non-study participants to verify the number and order of the questions in the study. Interviews were conducted based on the willingness of participants in any place where they were set, and each interview time ranged between 30 and 45 minutes. Interviews were recorded and then transcribed verbatim, and they were analyzed twice after the interview. In addition to the interviews, some of the related documents were analyzed to understand the content of TSL and other related concepts of subsidy in the context of Iran. The Framework Approach was used to analyze the data assisted by the MACQDA 10 (VERBI software, Germany). Based on this approach, the data were analyzed in five stages, i.e., familiarization, identifying a thematic framework, indexing, charting or mapping, and interpretation. After coding all texts and extracting issues and sub-themes, the main themes were created by interpretation of the content in categories. Two researchers conducted coding to increase the validity. In addition, we asked researchers and several faculty members who were familiar with the analysis of qualitative research to review some of the interviews, codes, and extracted class to examine the validity of this coding.

\subsection{Ethics statement}

An introduction letter was prepared from the Tehran University of Medical Sciences (TUMS), and it was given to the participants. All participants were informed about the purposes of the study before the interviews. Participation 
in the study was voluntary, and the participants were free to leave or stop the interview at any stage. Participants were assured that the confidentiality of their information would be maintained. The Research Council in the School of Public Health at TUMS approved the study (No. 9021557003, August 12, 2014).

\section{Results}

Two themes were extracted during the first stage of the analysis, i.e., "Factors affecting inequity in the health system" and "Inappropriate policy making of TSL in the health sector." Also, five sub-themes and 24 issues were extracted from the interviews (Table 2).

Table 2. The thematic framework explaining the themes, sub-themes and issues

\begin{tabular}{|c|c|c|}
\hline Theme & Sub theme & Issue \\
\hline \multirow[t]{2}{*}{$\begin{array}{l}\text { Factors affecting } \\
\text { inequity in the health } \\
\text { system }\end{array}$} & $\begin{array}{l}\text { Health system structural } \\
\text { factors }\end{array}$ & $\begin{array}{l}\text { - Lack of attention to equity } \\
\text { - The regressive HCF } \\
\text { - The high cost of treatment in comparison with healthcare } \\
\text { - Lack of unity in the financing strategy } \\
\text { - Inappropriate function of the insurance system }\end{array}$ \\
\hline & $\begin{array}{l}\text { The Socioeconomic } \\
\text { factors }\end{array}$ & $\begin{array}{l}\text { - High liquidity and inflation rate } \\
\text { - High income inequality } \\
\text { - Oil-dependent economic structure } \\
\text { - Lack of transparency of financial processes } \\
\text { - A large informal sector to the formal sector }\end{array}$ \\
\hline \multirow[t]{3}{*}{$\begin{array}{l}\text { Inappropriate policy } \\
\text { making of TSL in } \\
\text { health sector }\end{array}$} & $\begin{array}{l}\text { Defects in formulation } \\
\text { of the policy }\end{array}$ & $\begin{array}{l}\text { - Disconfirmation with basic rules } \\
\text { - Lack of attention to the health system experts opinion } \\
\text { - Weakness of theoretical concepts and models } \\
\text { - Lack of systematic approach to the result of law on health } \\
\text { system } \\
\text { - Lack of Empowerment Approach and domination of } \\
\text { results-oriented approach) } \\
\text { - Time limitation }\end{array}$ \\
\hline & $\begin{array}{l}\text { Defects in } \\
\text { implementation of the } \\
\text { policy }\end{array}$ & $\begin{array}{l}\text { - Non-compliance of the law implementation with the law } \\
\text { formulation } \\
\text { - Lack of attention to the inequality and equity in } \\
\text { implementation } \\
\text { - Lack of TSL resource allocation to the health sector } \\
\text { - Fragmentation of resources obtained from law } \\
\text { - Lack of needed economic and political infrastructures }\end{array}$ \\
\hline & $\begin{array}{l}\text { Defects in evaluation of } \\
\text { the policy }\end{array}$ & $\begin{array}{l}\text { - Simultaneous other economic and political events with } \\
\text { the law implementation } \\
\text { - Lack of appropriate indicators Shortages of targeted } \\
\text { subsidies law evaluation }\end{array}$ \\
\hline
\end{tabular}

\subsection{Theme 1: Factors that affect the inequity in the healthcare system}

The main defects that create barriers to the appropriate implementation of the equity in HCF are provided in this theme. This theme was divided in two sub-themes, i.e., the health system structural factors and the barriers related to the structure of the macro-economic system.

3.1.1. Structural factors of the health system

Based on the interviewees, some of the health system and health financing internal factors have created barriers for improving equity in Iran's health system. One of the main reasons of inequity in the HCF is lack of attention to equity in the cost of resources by MoHME. Some of the participants stated that the health system was unable to make the equity in its process because of weaknesses in its performance, and this is the cause of inequity in HCF. "MoHME have to pay attention to the equity in the coasting of the resources ... They have done many about but it appears low, they most attention to equity at least in health financing" (a member of parliament). "Of course, there are many reasons for HCF inequity; one of them can be an inappropriate performance of the health system..." (An expert from MoHME). Regressive financing, in which poor people participate more than rich people in financing, is a notable inequitable method of HCF. Some interviewees believed that Iran's HCF is regressive and that this causes 
inequity in the system. "We know that Iran's HCF is regressive, not proportional or progressive... this is the major problem of our financing ... with this method of financing, we give indirect subsidies to the riche not the poor ..." (A senior director from MoHME). Some of the participants stated that the high share of costs associated with the treatment compared to the costs associated with healthcare in the Iran's health system creates a moral hazard and decreases the possibility of health resource management. This kind of mismanagement decreases the effects of health system reforms. "If we spend more money in healthcare instead of treatment ...MoHME can properly manage its funds ... can switch from fee for service to capitation payment method..." (Member of Parliament). In addition, lack of clearer and precise strategy for financing is another factor that interviewees emphasized. "We saw a lack of efficiency and inequity in the health system ... I think this is because of lack of unity in financing strategies that...." (An expert from SSO).

\subsubsection{Socioeconomic factors of society}

This theme is related to the main factors behind the health system structure, the socioeconomic context, which affect the equity in HCF. The majority of the study participants stated that the inequity in HCF comes from macro socioeconomic situation. Based on their views, when society has inequality and inequity in total socioeconomic structure, we cannot expect equity in sartorial system or in the health system. "We have to look holistically to the issue ... the health system is a part of the society, so if we have problems in total social structure, these will flow to sub sectors assuredly" (a director from MoEF). "...with inflation, unemployment and inequality in the overall level of society ...reducing of inflation and inequality in other sectors are impossible" (a deputy from CBIR). The high level of liquidity in the community was one of the main points raised by study participants' views. Interviewees believed that wrong monetary and fiscal policies caused the high level of inflation in the community, which has negative effect on sub-sectors of the society. One of the negative effects of high liquidity on the health system was the rising cost of the healthcare system because of the changes in the formal and informal tariffs of health services. "Iranian economic has one of the high levels of liquidity in EMRO ...this caused high level of inequality in community" (an advisor from MPO). “... Income inequalities in society rooted in the money supply and increase its liquidity... inflation rate increases ...the purchasing power of a currency becomes less and people allocate their income to essential needs like food not to healthcare" (a deputy from MoEF). In addition to the inflation rate and liquidity, the high level of income inequality was the main emphasis of the participants as factor that affected social and health system inequality. Some of them mentioned that the Gini coefficient had a high level in Iran compared with other countries in the region. "... income inequality rate had no more tolerance and different economic policies had little effect on Gini coefficient... we have a high rate of income inequality today..." (A university professor). According to the interviewees, the oil-dependent economy is the most important factor that affects equity in HCF. Fluctuations in oil prices in international markets severely affect oil-dependent economies. The high share of the Iran's health system's budget depends on the government's public budget that comes from oil sales. Obviously, the change in the price of oil affects the sector's budget, including the health system's budget. "Oil-depended economy is our biggest problem... fluctuations in oil prices affects our economy...we do not plan to manage our resources" (an expert from OTS). According to the interviewees, the lack of financial transparency is another deficiency in Iran's economy that caused inequality in the community. Lack of financial transparency has a negative effect on the tax system's function and that is why Iran's economy faced inequity. "Our tax system does not work properly, especially in the area of identifying financial processes ... harmful for social justice" (a deputy from CBIR).

\subsection{Theme 2: Inappropriate policy making of TSL in the health sector}

This theme refers to the main defects that occurred in the process of the policy in the health sector. For this purpose, participants' points of view were categorized into three sub-themes, i.e., formulations, implementation, and evaluation defects of the policy.

\subsubsection{Defects in formulation of the Policy}

An important issue in the TSL formulation was non-compliance of the policy executive bylaw with the upstream documents. Some of interviewees mentioned that the TSL formulation in the health sector must be in accordance with upstream documents, such as the Comprehensive Social Security System. However, policy makers did not consider it in developing its executive bylaws. "...Paragraph B of Article 7 of the TSL should be formulated in terms of the Comprehensive Social Security System, ... was not compliance completely... and there are more difference between them..."( Senior health deputy). Lack of attention to health experts' views in the policy formulation process was one of the important defects that some of the participants stated.

"They didn't invite us to cooperate in the policy formulation and the policy was formulated without health expert interventions..." (A senior director of MoHME). In addition to ignoring the views of experts, another defect to the policy formulation was lack of theoretical principles and an appropriate model in the policy formulation process. 
Some of participants stated that there was no well-defined model available to formulate the law in the health sector. "There was not any model for policy formulation..., especially in the health sector it was a big problem that it made unpredicted problems for health system..." (A director of OTS). "...Theoretical principals that should support the TSL formulation in the health sector were not strong enough..." (An expert from IPRC). Some participants acknowledged that some of the reforms, such as TSL, created total structural failure. Accordingly, policy makers should be cautious ahead about the consequence of implementation such policies. "Due to structural failure of the... and TSL, the result of the policy implementation was unpredictable ...this was a big problem in beginning of policy formation” (an expert from MoCLS) “...we couldn't find an appropriate model for TSL because structural failure is unavoidable ..." (a senior director from SSO). Some of the interviewees emphasized that the prevailing view concerning the entire of the law was results-oriented, not empowerment-based, therefore, in formulating the policy for the health sector, the prevailing view was focused on treatment rather than reforming the structure. “...one of the reasons for failure of the law implementation... in the health sector was the lack of attention to structural reform of the health system in formulation phase..." (An expert from OTS). "Result-oriented view was dominated..., in fact; they wanted to treat the cause not reforming the structure" (a consultant from MPO). Time limitation was another defect of the formulation of the law that some of experts noted. This limitation affected TSL totally. "...TSL was prepared in a short time, which exacerbated the formulation error..." (a vice president of OTS). 3.2.2. Defects in implementation of the Policy

After the approving the TSL in Majlis in 2009, the law's implementation was started in 2010. This theme is about the main defects of the law's implementation in the health sector. Many of the participants thought that the main defects of the policy process in the health sector were non-compliance of performing and approving of the law. They believed that the law was not correctly performed, because the implementation process completely differed from the law that was approved by Majlis. "The law that approved in 2009 completely differs from what is implementing right now... actually it isn't TSL" (a member of parliament). "...I think because of the law deviation from approved law... we didn't achieve our goals for health system" (One of the vice president of MoCLS). Many experts believed that this kind of the law implementation did not include important concepts, such as inequality and equity. In fact, interviewees believed that the TSL failed to meet its objectives. Some of the experts stated that the implementation method of the TSL exacerbated inflation accordingly; it is not based on justice. "... was created severe complications and was increased pressure on public employee and exacerbated poverty... finally have had negative effect on health system like other sectors" (an advisor from MPO). "This law was not equity based totally..." (A member of parliament). According to the interviewees, because of incorrect implementation and non-compliance with the formulated law, considered objectives, including the health system's objectives, were not fulfilled. The major part of the sources obtained from the TSL shifted to cash payment and no monet was left for other versions of the TSL or for article 7 of the policy. "Article 7 of the TSL ... has not been implemented until today because there was not enough money" (an expert from OTS). "They didn't pay for the health system from sources obtained from the TSL ...this was a major problem of policy implementation..." (An expert from OTS). Some of the experts acknowledged that the government forced to use additional financial resources, such as the annual budget, to prepare sufficient money for cash payment. A high level of cash payment to people increased the inflation rate, and this put vulnerable households under pressure and caused income inequality more than before. "If total obtained resources from energy price was equal with total cash payment, the effect of inflation were restricted. But cash payment was doubled and inflation rate increased" (a deputy from IPRC). "In implementation, government had paid to all of the people equally ...goals was not achieved." (An expert from OTS). Based on the interviewees' opinions, fragmentation of the resources obtained from the TSL was another reason for the limitations of the policy. The government, when faced with a lack of resources for any policy, used TSL as the source of required resources. These were the main defects of the TSL in achieving its objectives. "...Unfortunately, everywhere the government faced to budget deficit, the TSL was the first resolve... This caused to fragmentation of the TSL..." (An expert from IPRC). Some of the participants emphasized that the policy's implementation must provide appropriate socioeconomic capacities, such as a low inflation rate, lack of stagnation, and the possibility of controlling tariffs in favor of the manufacturing sector. Nevertheless, at that time, these preconditions were not prepared completely. "...targeted subsidy is not recommended in recession condition because it can make main risks to the country manufacturing ...unfortunately these were not considered at the start of the policy..." (A senior director of SSO).

3.2.3. Defects in evaluation of the Policy

Interviewees mentioned some factors about the TSL defects in the health sector that can be considered as policy evaluation. One of those factors was concurrency of implementation of this policy and other political and economic events. Among these events, the formation of broad sanctions against Iran and the increase of the exchange rate had a greater impact on the Iranian economy. Some participants acknowledged that these events, especially broad sanctions, had intereferring effects with the TSL, and, therefore, the evaluation of the policy was limited. “... One of 
the policy evaluation challenges, which make unclear the impact of the law, was that we was facing different international sanctions..." (A director of MoCLS). "An important event took place at the end of the 2011 and early 2012, was a quick increase of exchange rate. This led to ...the increase of total medicines and equipment costs strongly..." (An advisor from MPO). Lack of a control group to compare with the case group to evaluate the implementation of TSL was another defect in this area. In addition, some of the participants mentioned that there were not similar international experience in this regard for comparing the results. "Policy evolution needs to targeted groups to compare before and after about the effect of policy implementation... we hadn't this in Iran and in the world. In fact, we do not know if the TSL was not implemented what could be happened" (a senior director from MoEF). In addition, the lack of appropriate indicators to assess the effects of the policy, especially on the health system, was a factor that was emphasized in interviewees' viewpoints. "Unfortunately, there was no index for the policy evaluation ... We do not know the exact effect of the TSL on agriculture... and healthcare system" (a vice president of MoEF).

\section{Discussion}

This study offers a clear framework ( $5^{\text {th }}$ sub-theme) to understand and analyze fair financing of health system challenges in Iran based on the TSL implementations. In this part, the main HCF challenges faced by TSL in making equitable HCF were discussed. Equity in healthcare financing is an important issue in all health systems, especially in developing countries that have high rates of out-of-pocket (OOP) expenses. These countries formulate and implement different policies to achieve fair financing of their health systems and to decrease CHE for households (25-27). Lack of financial resources and inappropriate distribution of the available resources were some of the important defects in the implementation of the programs and policies in the health sector to decrease CHE (28). Iranian HCF, like other developing country, is no exception, and its HCF is unfair. Fair Financing Contribution Index (FFCI) for Iran in different studies are regressive, showing the unfair HCF (18, 21, 29). Two studies by Hajizadeh (2009 and 2010) considered Iran's HCF progressivity and showed that it was regressive over the last decade $(17,19)$. However, this means that the formulated policies for decreasing inequity in financing of the health system have not been effective. Regressive HCF has a negative effect on the output of justice-based policies, because it is one of the factors identified in Iran for the implementation of universal health coverage (30). Some of the fair financing indices, such as CHE, were not decreased after the implementation of TSL, and this shows that TSL had no effect on the health system $(18,21,31)$. The health system's weakness in the distribution of its resources is another factor that caused unfair HCF. MoHME did not pay enough attention to equity and equality in its resource distribution $(32,33)$. These disabilities are, to some extent, related to the lack of transparency in financial processes. Financial transparency has more effects on the health system, and it can facilitate the process or create barriers in achieving the desired goals. A 2011 study by Ibrahimipour, for instance, showed that one of the barriers in running the universal health coverage system in Iran was the lack of transparency in the financial processes of the health system (30). Our study concluded that, at the macro level of society, the lack of financial process transparency was determined as elements of injustice that can have an effect on sub-sectors' financial transparency, as well as the health system. Structural reform of health insurance affects the health system's outputs, including HCF. Choosing an equitable insurance structure can decrease OOP payments (34). Health insurance's weakness was mentioned as one of the affecting factors on fair financing of the health system (35). In this study, health insurance weakness was seen as an important factor that affected the health system's structural weakness concerning equity. In this study, some of the socioeconomic factors were identified as important factors that affected on the equity in HCF. There is more evidence of the association between socioeconomic factors, such as economic capital (income inequality and financial stress) and health outcomes (36-38). The importance of both economic and social factors in health differences between countries was apparent. Economic factors were determined as the most important factors in health differences than the other elements of the health system (39).

The high rate of inflation because of high rate of liquidity is one of the causes of inequality in society. The high share of inflation rate in Iran is because of monetary and fiscal policies of the government (11). Furthermore, social justice damaged by the high inflation rate because the fixed income revenue owners, such as retirees' and pensioners' concessions, lose their purchasing power and poverty and social inequality will increase (40). In Iran, where the annual budget and the economic status depends on revenue from oil exports (41), oil-price shocks can have considerable effects on the economy. These shocks, negative or positive, change the inflation rate in society. As noted earlier, the inflation rate has a negative correlation with income inequality. This income inequality is spread at the community level and can be seen in other sectors of the society as well as in the health system. In recent years, when the price of oil decreased dramatically, the oil exporting countries encountered more shocks to 
their economies. The negative shocks of oil prices decreased oil revenue, and this caused pressure on society because of the budget deficit, which affected sectorial budgets, such as the health system, in an unfair manner. Every time the government's share of healthcare expenditures decreased, the health system offset its costs by increasing OOP payments (42-45). In recent years, the government of Iran has implemented various policies to decrease its dependency on oil export revenue. Some of these policies were based on optimizing the resource utilization. The high share of per capita energy consumption and the payment of subsidies to energy had put the government under budget pressure. These were the reasons TSL was formulated by Iran's government. Phasing out subsidies has several short-run and long-run economic impacts. Short-run effects of the policy are changing in prices of transport, cost of production, household income and consumption, and the government's budget. Changing in investment, balance of trade, and other economic and social variables were considered as long-run impacts of phasing out subsidies (46). TSL was based on liberalization of energy prices, so some experts believed that direct subsidies were dependent on shocks in oil prices, and their fluctuations caused the government to be passive in policy formulation and decision-making in the distribution of subsidies (6). Paying cash subsidies and gradual elimination of energy subsidies were governmental strategies to promote the efficiency of energy consumption and to improve social equity by protecting vulnerable groups (15). Theoretical principles emphasized that every general economic policy affected other social sectors, including the health system (47). Accordingly, it was thought that based on component of the policy, the TSL must have a positive effect on healthcare and social welfare. But the finding of the studies showed that implementation of the TSL had a negative effect on population's health behavior and the healthcare system in general $(6,15)$.

In addition to defects related to policy formulation, the experts mentioned that the defects and problems associated with policy implementation were the major factors in achieving the intended objectives of TSL. In fact, the law implementation was generally different with what was formulated. and, because of this, except for cash payment, other principles of the law were not considered. Based on the approved law (Paragraph A of Article 7 of the law), the government, according to households income level, must share the resources that come from TSL (Up to 50\% of the resources) between income deciles (16). However, in practice, the government paid equal subsidy to the entire population. In addition to the equal cash payment to the richest and poorest, lack of attention to the experts and specialists was another policy process problem. According to the economic experts, the government had to provide the administrative infrastructure for optimized implementation of the policy. One of the important parts of the infrastructure was the population's financial database. A reliable database leads to the correct identification deciles and equitable redistribution of the resources $(48,49)$. This study showed that this shortage has created more problems in the policy process. The lack of a database leads to an inappropriate tax system, and government revenues will not be transparent and stable $(50,51)$. Health system for service delivery needs resources from the government as Gross Governmental Health Expenditures (GGHE). Equal cash payment caused the deficit in TSL resources, and, because of this, the government was faced with the problem of paying direct subsidies every month (52). This caused the government to be unable to allocate approved budgets to health sector. One of the reasons for inequity in the healthcare financing and increasing out of pocket is reducing of GGHE (53). A systematic approach to the effects of the structural reforms and policy implementation is necessary (54). The policy formulation defects intensified the policy implementation problems. The impossibility of simulating the results of TSL because of the lack of tested appropriate theoretical concepts and models decreased the ability to create reasonable policies. In order to simulate the results, we must model the theoretical principles. As a result, the lack of the theoretical principles blinded policy makers to simulating the results of policy implementation. However, in the TSL implementation according to this problem, there was no systematic approach to determine the effects of the the law; instead, the results-oriented approach was dominant. This caused policy makers to fail to see the secondary effects of the implementation of the policy on different sectors of the society. One of the results that the law enforcers couldn't predict was that individuals would spend their money on necessary needs, including food and housing, instead of healthcare $(11,40)$. Some of the health system's reforms, such as Family Physician, were piloted in parts of the country. Nevertheless, the TSL without any previous experience was implemented nationwide. Some of the experts emphasized that this was because of the time limitation in the policy process. The time limitation led to a lack of focus on the effects of the law $(55,56)$.

After the Islamic revolution in 1978, Iran has always facing unilateral and multilateral sanctions. Coincident with the issue of Iran's development of peaceful nuclear energy in 2010, western countries imposed severe sanctions against Iran $(57,58)$. Furthermore, the exchange rate in the country, in a short time, increased and reached three times its earlier level (10). Both of these events had special effects on the economy. These effects stunted the evaluation of the TSL's real implementation effects on society at large. Thus, there were no appropriate indexes to 
evaluate the policy's effects on society or the health system. The lack of indexes led to more barriers for determining the real effect of the policy. This is the first study to consider the defects prior to the implementation of TSL to achieve its intended goals in the health sector. Data collection from different related experts from different perspectives to policy process (formulation, implementation and evaluation) is the strength of the study. The study's findings helped identify the factors that have the greatest effect on the equity in HCF in Iran with regard to the implementation of a large-scale social policy. These findings can help policy makers in formulating and implementing appropriate policies in accordance with the existing structures and the potential of the community.

The limitations of this qualitative study should be taken in account. It was not intended for the results to be generalized. Data collectors and interviewers' biases should be taken into consideration. For this purpose, some transcripts were sent to interviewees to increase the validity of the findings. It seems that a quantitative longitudinal study before and after TSL on the equity in health financing in Iran can enrich the findings of this study.

\section{Conclusions}

This study showed that the TSL in the way of achieving its goals, especially in the field of health, faced various shortcomings and defects. One of the important results of this study was that, in addition to socioeconomic factors, the health system's structural problems should be considered for achieving an equitable health system. We concluded that there is a need for a general review of the TSL legislation process based on this study's findings, and various barriers must be considered, as identified in our research, when the related policies are designed. Eventually, quantitative studies are needed with time series design to identify the impact of TSL on the indicators of equity in the health system (such as out-of-pocket (OOP) expenses and catastrophic healthcare expenditures).

\section{Acknowledgments:}

The authors would like to acknowledge the Tehran University of Medical Sciences (TUMS) for the financial support it provided for this study. Our special gratitude goes to M. H. Ziloochi, M. Alipouri Sakha, H. Mostafavi, Dr. H. Pourasghari, T. Zahirian Moghadam, S. Delavari, and Dr. Emami Razavi for their scholarly contributions in providing data and facilitating the study. The research project was sponsored by the Tehran University of Medical Sciences (TUMS), grant number "9021557003."

\section{Conflict of Interest:}

There is no conflict of interest to be declared.

\section{Authors' contributions:}

All authors contributed to this project and article equally. All authors read and approved the final manuscript.

\section{References}

1) Rudenko DY, Pogodaeva TV, Didenko NI. Poverty Alleviation Strategies in the Russian Arctic Zone Regions. Mediterr J Soc Sci. 2015; 6(1): 32. doi: 10.5901/mjss.2015.v6n1p32.

2) Mills A, Ataguba JE, Akazili J, Borghi J, Garshong B, Makawia S, et al. Equity in financing and use of health care in Ghana, South Africa, and Tanzania: implications for paths to universal coverage. Lancet. 2012; 380(9837): 126-33. doi: 10.1016/S0140-6736(12)60357-2.

3) Prakongsai P, Limwattananon S, Tangcharoensathien V. The equity impact of the universal coverage policy: lessons from Thailand. Adv Health Econ Health Serv Res. 2009; 21: 57-81. PMID: 19791699.

4) suchasnoi ekonomiky Makmillana S. Macmillan Dictionary of Modern Economics. Kyiv: ArtEk. 2000.

5) Buigues PA, Sekkat K. Public subsidies to business: an international comparison. J Ind Compt Trade. 2011; 11(1): 1-24. doi: 10.1007/s10842-010-0074-1.

6) Yousefi A, Karbasi P, Amini Am, editors. The impact of Iranian Targeted Subsidy Plan on the Comparative Advantage of Dairy Farms. International Conference on Energy, Regional Integration and Socio-economic Development; 2013: EcoMod.

7) Mohamadi T, Pajhoyan J, Abbaszadeh S. The impact of energy subsidies elimination on GDP in Iran. Applied Economics. 2010; 2: 1-24.

8) Azarbaiejani K, Hamedani AS, Bahaloo M. An analysis of the effect of energy subsidies decrease and transfer payments to households on social welfare in Iran. Interdiscipl J Contemp Res Bus. 2012; 4(1): 478.

9) Domehri M, Shams D. Inflammation Growth in IRAN (Islamic Republic of): Causes and Treatments. Life Sci J. 2013; 10(1). http://www.lifesciencesite.com. 
10) ICB ICB. inflation rate Tehran, Iran2014. Available from: http://www.cbi.ir/simplelist/1589.aspx.

11) Liu O, Adedeji O. Determinants of inflation in the Islamic Republic of Iran: A macroeconomic analysis. (2000) IMF Working Paper No. 00/127. Available from: http://ssrn.com/abstract=879891.

12) Reza Farzin M, Guillaume DM, Zytek R. Iran-The Chronicles of the Subsidy Reform. IMF Working Papers. 2011:1-28. Available from: http://ssrn.com/abstract=1888910.

13) Organization WH. The world health report 2000: health systems: improving performance: World Health Organization; 2000.

14) Alderman $\mathrm{H}$. The effect of food price and income changes on the acquisition of food by low-income households: Intl Food Policy Res Inst.1986. doi: 10.1016/j.worlddev.2013.01.021.

15) Doshmangir L, Doshmangir P, Abolhassani N, Moshiri E, Jafari M. Effects of Targeted Subsidies Policy on Health Behavior in Iranian Households: A Qualitative Study. Iran J Public Health. 2015; 44(4): 570-9. PMID: 26056676, PMCID: PMC4441970.

16) MAJLIS. Targeted subsidies law Tehran: the Parliament of Islamic Republic of Iran (Majlis) 2009. Available from: http://www.parliran.ir/index.aspx? siteid=1\&pageid=3070.

17) Fazaeli AA, Ghaderi H, Fazaeli AA, Lotfi F, Salehi M, Mehrara M. Main Determinants of Catastrophic Health Expenditures: A Bayesian Logit Approach on Iranian Household Survey Data (2010). Global J Health Sci. 2015; 7(4): 335. doi: 10.5539/gjhs.v7n4p335.

18) Moradi A. Equity of Health Care Financing: An Application to Iran. 2011. Available from: https://mpra.ub.uni-muenchen.de/id/eprint/33489.

19) Hajizadeh M, Connelly LB. Equity of health care financing in Iran: the effect of extending health insurance to the uninsured. Oxf Dev Stud. 2010; 38(4): 461-76. doi: 10.1080/13600818.2010.524697.

20) Hajizadeh M, Connelly LB. Equity of health care financing in Iran. 2009. Available from: https://mpra.ub.uni-muenchen.de/id/eprint/14672.

21) Zakeri M, Olyaeemanesh A, Zanganeh M, Kazemian M, Rashidian A, Abouhalaj M, et al. The financing of the health system in the Islamic Republic of Iran: A National Health Account (NHA) approach. Med J Islam Repub Iran. 2015; 29(1): 659-66.

22) Wagstaff A, Van Doorslaer E, Van der Burg H, Calonge S, Christiansen T, Citoni G, et al. Equity in the finance of health care: some further international comparisons. J Health Econ. 1999; 18(3): 263-90. doi: 10.1016/S0167-6296(98)00044-7. PMID: 10537896.

23) Organization WH. World health statistics 2010: World Health Organization; 2010. ISBN: 978924156398 7.

24) Anbari Z, Mohammadbeigi A, Mohammadsalehi N, Ebrazeh A. Health Expenditure and Catastrophic Costs for Inpatient-and Out-patient Care in Iran. Int J Prev Med. 2014; 5(8): 1023-8. PMID: 25489451, PMCID: PMC4258666.

25) Organization WH. The world health report 2000: health systems: improving performance: World Health Organization; 2000.

26) Wagstaff A, van Doorslaer E. Progressivity, horizontal equity and reranking in health care finance: a decomposition analysis for the Netherlands. J Health Econ. 1997; 16(5): 499-516. doi: 10.1016/S01676296(97)00003-9. PMID: 10175628.

27) Wagstaff A, Van Doorslaer E. Equity in the finance of health care: some international comparisons. J Health Econ. 1992; 11(4): 361-87. doi: 10.1016/S0167-6296(98)00044-7.

28) Raykar NP, Yorlets RR, Liu C, Greenberg SL, Kotagal M, Goldman R, et al. A qualitative study exploring contextual challenges to surgical care provision in 21 LMICs. Lancet. 2015; 385: 515. doi: 10.1016/S01406736(15)60810-8.

29) Daneshkohan A, Karami M, Najafi F, Matin BK. Household catastrophic health expenditure. Iran J Public Health. 2011; 40(1): 94-9. PMID: 23113061. PMCid:PMC3481728.

30) Ibrahimipour H, Maleki M-R, Brown R, Gohari M, Karimi I, Dehnavieh R. A qualitative study of the difficulties in reaching sustainable universal health insurance coverage in Iran. Health Policy Plan. 2011; 26(6): 485-95. doi: 10.1093/heapol/czq084.

31) Moghadam MN, Banshi M, Javar MA, Amiresmaili M, Ganjavi S. Iranian household financial protection against catastrophic health care expenditures. Iran J Public Health. 2012; 41(9): 62-70. PMID: 23193508, PMCID: PMC3494217.

32) Zandiyan H, Ghiasvand H, Nasimi DR. Measuring Inequality of Distribution of Health Resources: A Case Study. Payesh. 2012; 6: 799- 805. 
33) Mostafavi H, Aghlmand S, Zandiyan H, Alipoori Sakha M, Bayati M, Mostafavi S. Inequitable Distribution Of Specialists And Hospital Beds In West Azerbaijan Province. Payavard Salamat. 2015; 9(1): 55-66.

34) Mitenbergs U, Brigis G, Quentin W. Healthcare financing reform in Latvia: Switching from social health insurance to NHS and back? Health Policy. 2014; 118(2): 147-52. doi: 10.1016/j.healthpol.2014.09.013, PMID: 25445111

35) Carrin G, Waelkens MP, Criel B. Community - based health insurance in developing countries: a study of its contribution to the performance of health financing systems. Trop Med Int Health. 2005; 10(8): 799811. doi: 10.1111/j.1365-3156.2005.01455.

36) Laaksonen E, Martikainen P, Lahelma E, Lallukka T, Rahkonen O, Head J, et al. Socioeconomic circumstances and common mental disorders among Finnish and British public sector employees: evidence from the Helsinki Health Study and the Whitehall II Study. Int J Epidemiol. 2007; 36(4): 776-86. doi: 10.1093/ije/dym074.

37) Lorant V, Croux C, Weich S, Deliege D, Mackenbach J, Ansseau M. Depression and socio-economic risk factors: 7-year longitudinal population study. $\mathrm{Br} \quad \mathrm{J}$ Psychiatr. 2007; 190(4): 293-8. doi: 10.1192/bjp.bp.105.020040.

38) Muhammad Malik A, Azam Syed SI. Socio-economic determinants of household out-of-pocket payments on healthcare in Pakistan. Int J Equity Health. 2012; 11: 51. doi: 10.1186/1475-9276-11-51, PMID: 22947067. PMCID: PMC3478199.

39) Carlson P. The European health divide: a matter of financial or social capital? Soc Sci Med. 2004; 59(9): 1985-92. doi: 10.1016/j.socscimed.2004.03.003.

40) Dorrance GS. The Effect of Inflation on Economic Development (Les conséquences de l'inflation sur la croissance économique)(Los efectos de la inflación sobre el desarrollo económico). Staff PapersInternational Monetary Fund. 1963: 1-47. doi: 10.2307/3866064.

41) OPEC. Annual Report 2014. Vienna, Austria: Organization of the Petroleum Exporting Countries Public Relations and Information Department, 2014. ISSN: 0474-6317.

42) Coburn D. Income inequality, social cohesion and the health status of populations: the role of neoliberalism. Soc Sci Med. 2000; 51(1): 135-46. doi: 10.1016/S0277-9536(99)00445-1

43) Farzanegan MR, Markwardt G. The effects of oil price shocks on the Iranian economy. Energ Econ. 2009; 31(1): 134-51. doi: 10.1016/j.eneco.2008.09.003.

44) Karl TL. Oil-led development: social, political, and economic consequences. Encyclop Energ. 2007; 4: 661-72.

45) Ahnquist J, Wamala SP, Lindstrom M. Social determinants of health-a question of social or economic capital? Interaction effects of socioeconomic factors on health outcomes. Soc Sci Med. 2012; 74(6): 930-9. doi: 10.1016/j.socscimed.2011.11.026.

46) Abouleinein S, El Laithy H, al-Dīn HK. The impact of phasing out subsidies of petroleum energy products in Egypt: Egyptian Center for Economic Studies; 2009.

47) Sterman JD. Business dynamics: systems thinking and modeling for a complex world: Irwin/McGraw-Hill Boston; 2000. ISBN: 978-0-07-231135-8.

48) Au F, Prahardhi S, Shiell A. Reliability of two instruments for critical assessment of economic evaluations. Value Health. 2008; 11(3): 435-9. doi: 10.1111/j.1524-4733.2007.00255.x.

49) Bastianoni S, Coscieme L, Pulselli FM. The input-state-output model and related indicators to investigate the relationships among environment, society and economy. Ecol Model. 2014. doi: 10.1016/j.ecolmodel.2014.10.015.

50) Askari H, Cummings JT, Glover M. Taxation and Tax Policies in the Middle East: Butterworths Studies in International Political Economy: Elsevier; 2013. ISBN: 0-408-10832-0.

51) Keshavarzian M, Mofidian S. An Overview on Iran Health Care Financing System: Challenges and Solutions. 2014.

52) Zamanzadeh H. Targeted subsidies: Achievements, challenges and costs. Tazehaye Egtesad. 2011; 9(133): 108-16.

53) Xu K, Saksena P, Jowett M, Indikadahena C, Kutzin J, Evans DB. Exploring the thresholds of health expenditure for protection against financial risk. World health report. 2010: 328-33.

54) Anderson CR, Paine FT. Managerial perceptions and strategic behavior. Acad Manag J. 1975; 18(4): 811 23. doi: $10.2307 / 255380$. 
55) Majdzadeh R. Family physician implementation and preventive medicine; opportunities and challenges. Int J Prev Med. 2012; 3(10): 665-9. PMID: 23112890, PMCID: PMC3482991.

56) Takian A, Doshmangir L, Rashidian A. Implementing family physician programme in rural Iran: exploring the role of an existing primary health care network. Fam Pract. 2013; 30(5): 551-9. doi: 10.1093/fampra/cmt025. PMID: 23788202.

57) Garver JW. 11 The US factor in Sino-Iranian energy relations. Sino-US Energy Triangles: Resource Diplomacy Under Hegemony. 2015: 207.

58) Nakanishi H. The Construction of the Sanctions Regime Against Iran: Political Dimensions of Unilateralism. Economic Sanctions under International Law: Springer. 2015; 23-41. doi: 10.1007/978-946265-051-0_2 